\title{
The Influence of Fiscal Position to the Socio-Economic Development of the Provinces in the Philippines
}

\section{Analiza Paña Aguilar*}

Department of Governance and Development Studies, College of Development Management of the University of Southeastern Philippines, Davao City, Region Xi Philippines

\begin{abstract}
This study on the Influence of fiscal position to the socio-economic development of the provinces in the Philippines is a quantitative research. Universal sampling was employed wherein all of the 83 provinces in the Philippines were included. Through the use of secondary data from various government agencies, the ultimate goals of this study are to determine the fiscal position of the provinces in terms of the 6 parameters namely, national government subsidy, income, operational expenditures, total assets, public debts, and budget surplus; to determine the socio-economic development of the provinces in terms of poverty incidence, attended mortality rate, professionally attended birth rate, and labor force participation rate; to determine if correlation exist between fiscal position and socioeconomic development using the Pearson product-moment correlation analysis; and to determine the degree of influence of fiscal position to socioeconomic development through multiple linear regression analysis.

The research undertaking concluded that in terms of fiscal position, Luzon regions are the richest while and Mindanao regions are the poorest; poverty incidence is lowest in Luzon regions especially in the NCR while highest in Mindanao most particularly in the Zamboanga Peninsula and in ARMM. Correlation analysis revealed that there is a strong negative relationship between fiscal position and poverty incidence; a very strong positive relationship between fiscal position and attended mortality rate; and a moderate positive relationship between fiscal position and professionally attended birth rate. Multiple linear regression analysis revealed that the influence of budget surplus to poverty incidence is statistically significant; and the influences of assets and public debts to professionally attended birth rate are statistically significant, assets having the greater influence. Meanwhile, none of the influences of fiscal position parameters to attended mortality rate is statistically significant.
\end{abstract}

Keywords: Socio-economic; Philippines; Research; Government

\section{Introduction}

The problem of how to reduce if not eliminate poverty has remained a predicament to leaders all over the globe and the international community, especially in Third World countries like the Philippines where poverty thrives. In order to help fight poverty, the United Nations (UN) declared 1996 as the "International year for the eradication of poverty" and October $17^{\text {th }}$ of each year as the "International Day for the Eradication of Poverty". Further, to address this precarious situation by waging war against the problem all over the globe, the International Community under the UN's patronage agreed on the Millennium Development Goals (MDGs) in the year 2000 with eradicating extreme poverty and hunger as the number one; and the Sustainable Development Goals in 2015 still with ending poverty in all forms everywhere as the first goal since the problem is tenacious.

One of the sub-components of this ever first goal is the need to reduce the proportion of people living on less than one US dollar per day and to reduce by half the proportion of people who suffer from hunger. This translates to reducing by half the number of people living on about P50.00 per day. Henceforth, many plans, policies, programs and strategies have been carried out by past administrations in the Philippines to alleviate poverty especially in the rural areas where poverty abounds. Nonetheless, estimates of poverty based on official poverty lines reveal that, in 2012, the latest year when nationally representative data on household incomes are available, 29.56 percent of our population were poor; with the ARMM as the region having the highest incidence of poverty (PSA [1]). Given the total projected population of 103 million Filipinos, there were about more than 30 million Filipinos across the country who are considered poor, that is basically at a ratio of one of every three Filipinos is living below the set poverty line.
According to Balisacan [2] poverty reduction in the Philippines has lagged far behind those of its East and Southeast Asian neighbors, mainly Indonesia, Thailand, Vietnam and China. Both China and Vietnam started with higher levels of poverty incidence than did the Philippines during the mid-1980s, but their absolute poverty soon dwindled and became much lower than the Philippines in the 2000s. Both Malaysia and Thailand also had virtually eliminated absolute poverty in just 20 years. Interestingly, while the Philippines had a much higher average income $(\$ 1,129$, in 2000 prices) in the mid-2000s than Vietnam (\$538) and Indonesia (\$942), its absolute poverty was actually much higher than either of the latter countries.

Much of what the public sees in media on the state of social development in the Philippines is the poverty in Metro Manila's slums. Yet, the poor in Metro Manila account for only 3.9\% of the country's poor population. Metro Manila's poverty incidence is also the lowest among the regions, with the four regions Western Mindanao, Bicol, Eastern Visayas, and ARMM having the highest incidence of poverty. What is quite remarkable is the very high spatial diversity of poverty and poverty reduction in the Philippines. In recent years, some regions have done quite well in attaining high per capita income growth and

*Corresponding author: Analiza Paña Aguilar, Department of Governance and Development Studies, College of Development Management of the University of Southeastern Philippines, Davao City, Region Xi Philippines, Tel: +09177025557; Email: analiza.aguilar@usep.edu.ph

Received November 03, 2017; Accepted November 30, 2017; Published December 07, 2017

Citation: Aguilar AP (2017) The Influence of Fiscal Position to the Socio-Economic Development of the Provinces in the Philippines. Review Pub Administration Manag 5: 232. doi:10.4172/2315-7844.1000232

Copyright: (c) 2017 Aguilar AP. This is an open-access article distributed under the terms of the Creative Commons Attribution License, which permits unrestricted use, distribution, and reproduction in any medium, provided the original author and source are credited. 
reducing poverty, but disturbingly others have experienced declines in per capita income and increases in poverty-note, for example, the alarmingly substantial increase of poverty in ARMM between 2006 and 2012. During this period, poverty also increased in Central Mindanao and CARAGA provinces. Viewed from an international perspective, such disparities have bred regional unrest, armed conflicts and political upheavals, thereby undermining the progress in securing sustained economic growth and national development (Reyes and Valencia).

According to Romualdez [3] in order to translate development objectives especially eradication of poverty into reality, financing is of course needed. In harmony with other measures, fiscal policies of the government are expected to generate more revenues and savings thus improving its fiscal position even to the extent of incurring public debts in order to finance development activities, such as, educating and keeping the populace healthy; providing economic programs to address livelihood and unemployment problems so to increase per capita production and income; controlling population growth; maintaining public order and safety; and conserving and protecting the environment among others. In other words, implementing development activities requires massive funding and reordering of fiscal activities. Therefore, it is necessary that developing countries have to work out the proper mix of revenue and expenditure policies to finance development and reduce, if not eradicate poverty. Using available provincial statistics, this research paper therefore, frameworks the regression analysis address towards determining the influence of provincial governments' fiscal position on the socio-economic development of the provinces. The main objective of this analysis is to support the careful interpretation of the fiscal factors that influence socio-economic development and to emphasize the need for policy makers and administrators to keep finding fiscal ways to reduce if not exterminate extreme poverty in the country.

\section{Objectives of the Study}

The main objective of the study is determining the influence of provincial governments' fiscal position on their incidence of poverty as well as the degree of influence of each of the parameters of the former to the latter. Explicitly, this exploration endeavours to:

1. Determine the fiscal position of the provinces in the Philippines in terms of national government subsidy, income, operational expenditures, total assets, public debts, and budget surplus;

2. Determine the socio-economic development status of the provinces in terms of poverty incidence, attended mortality rate, professionally attended birth rate, and labor force participation rate;

3. Test relationship between fiscal position and the socio-economic development of the provinces; and

4. Identify parameters of fiscal position that significantly influence socio-economic development.

\section{Significance of the Study}

Primarily the results of this analysis will provide useful information to fiscal administration authorities of the government such as the Congress, Department of Finance (DOF), the Department of Budget and Management (DBM), and the Development Budget Coordination Committee (DBCC) at the national level; and as well to the Sanggunians and local treasury and local budget offices at the local government level, as these will provide them some basis for making decisions relative to setting and hitting revenue targets; and to identifying or reordering expenditure priorities that significantly matter.
Secondly, to all of the spending units of the government, findings of this undertaking could provide them some inputs for designing programs and projects that will significantly help in reducing poverty especially those related to livelihood and employment as well as those allied to educating and keeping the populace healthy and productive.

Thirdly, the findings of this study could be a good take off point for further related researches of different scope to include other theoretically significant variables to poverty alleviation if not eradication.

Finally, for general readership, the researcher hopes that the results of this undertaking may offer expedient insights that will help make readers who maybe are concerned citizens or students of related fields, become better cognizant of the concept of public fiscal administration and development management.

\section{Definition of Terms}

The following terms are defined operationally:

\section{Attended mortality rate}

Attended mortality rate is part of the Philippine Health Statistics and is being regularly observed by the Department of Health (DOH) [4] on an annual basis. It is the percentage of the number of people who died that received proper medical attention or care, to the total number of deaths. The data used in the study are those of the years 2007 to 2012.

\section{Budget surplus}

Budget surplus refers to the savings or explicitly the year-end cash balances of the LGU. In this study it is the cumulative total of the yearend balances of all the component municipalities of each province. Data used are those published in COA's Annual Financial Report on Local Government Units for the years 2007 to 2012.

\section{Fiscal position}

Fiscal position is the financial status of the provinces for a six-year period, 2007-2012, determined by summing up those of their component municipalities. It is measured in terms of national government subsidy, income, operating expenditures, total assets, public debts, and budget surplus. Data are taken from the Annual Financial Reports on Local Government Units published annually by the COA.

\section{Income}

Income refers to the total revenue of all the component municipalities of each province, collected from various sources both tax and non-tax as provided in Book II of the Local Government Code of 1991. For this study, the data used are those published in COA's Annual Financial Report on Local Government Units for the years 2007 to 2012.

\section{Labor force participation rate}

Labor force participation rate is a measure of the active portion of the economy's labor force. It is the percentage of people who are either employed or actively seeking for employment to the total labor force population or those at the ages of 18 to 65 . The data for this study were taken from the Philippine Statistical Authority's (PSA) [5] Labor Force Survey (LFS) for the years 2007 to 2012.

\section{National government subsidy}

National government subsidy is the cumulative sum of the Internal Revenue Allotment (IRA), and all other appropriations given by the national government to the local government units. It is determined by summing up those of the component municipalities of each province. 
For this study, the data used are those published in COA's Annual Financial Report on Local Government Units for the years 2007 to 2012.

\section{Operational expenditure}

Operational expenditure refers to the total expenses incurred by all of the component municipalities each of the province. Data used are those published in COA's Annual Financial Report on Local Government Units for the years 2007 to 2012.

\section{Poverty incidence}

Poverty incidence is the percentage of families living below the income poverty threshold set by the government, to the total number of families in the respective provinces as reported in Philippine Statistical Authority's Full Year Official Poverty Statistics in the year 2006, 2009, and 2012.

\section{Professionally attended birth rate}

Professionally attended birth rate is part of the Philippine Health Statistics and is being regularly monitored by the Department of Health (DOH) [4] in an annual basis. It is the percentage of the number births attended by medical professionals such as doctors, nurses, and midwives to the total number of births. The data used in this study were those of the years 2007 to 2012.

\section{Public debts}

Public debts refer to the total liabilities of the component municipalities of each province for the years 2007 to 2012 as published in COA's Annual Financial Report on Local Government Units for the specified periods.

\section{Socio-economic development}

Socio-economic development of the provinces in this study is measured in terms of poverty incidence, attended mortality rate, professionally attended birth rate, and labor force participation rate. Data used are from 2007-2012 and were taken from the PSA and DOH $[4,5]$.

\section{Total assets}

Total assets are the balance sheet account that represents the value of all assets. For this study it is the cumulative total of all assets of the component municipalities of each province. Data used are those published in COA's Annual Financial Report on Local Government Units for the years 2007 to 2012 .

\section{Theory base}

The study is principally moored on the theoretical premise of the United Nations Development Program (UNDP) [6] that a country's fiscal position is a major instrument to generate a pattern of growth that maximizes poverty reduction, however subject to the constraining circumstances in each country. In other words, fiscal policy should foster pro-poor growth. This growth itself implies that the poor, however defined in a country context, disproportionately benefit in each period's growth increment. Achieving this outcome requires measures that assure the pro-poor distribution of that increment.

First, while macroeconomic instability usually harms the poor, policy frameworks aimed exclusively to securing such stability do not necessarily benefit the poor. Second, an option sometimes neglected involves giving greater emphasis to fiscal expansion through increasing public investments. While such fiscal expansion may generate government deficits, there is no longer a consensus that these are necessarily inflationary. UNDP supports forms of public investment that can provide a more long-term, durable basis for human development and poverty reduction. This implies capital accumulation and technological innovation that can deliver lasting gains to the poor. Third, inequality has been rising throughout developing and industrial countries since the 1990s. The reasons for rising inequality are still being debated though. Skill-based technological change seems to explain part of the phenomenon within countries. The weakening of labour unions and labour legislation, such as on minimum wages, has also contributed to widening disparities, particularly in middle-income developing countries. The policy implication of this rise in inequality is that fiscal measures are necessary to generate growth which is propoor. Much of the focus of traditional pro-poor fiscal analysis has been on expenditure switching policies that alter the pattern of government spending in favour of pro-poor public goods. However, budget reallocations are not sufficient to have a substantial impact on poverty when the distribution of productive assets is highly unequal. In these circumstances, policies that directly redistribute assets, such as land reform or construction of low-income housing, are essential initiatives. To materialize these development requirements, a country's fiscal position therefore must be sufficient enough if not beyond in order to finance these imperatives.

The above theoretical premise of the UNDP [6] conforms to the notion of Musgrave as cited in Briones [7] that development is expensive. Therefore, in order to translate the objective of eliminating extreme poverty, financing is highly needed. Additionally, to the development perspective of two of the most renowned authorities in the field of Public Administration and Governance, the Nigros Felix and Lloyd as cited in Leveriza [8] which advocates that sound financial position and administration is a fundamental requirement to national development.

\section{Conceptual Framework}

Presented in Figure 1 is the conceptual framework showing the variables of the study. The fiscal position is the independent variable with the parameters national government subsidy, income, operating expenditures, total assets, public debts, and budget surplus. The dependent variable is the socio-economic development status of the provinces measured in terms of poverty incidence, attended mortality rate, professionally attended birth rate, and labor force participation rate.

\section{Hypothesis of the Study}

Following are the alternative hypotheses of the study.

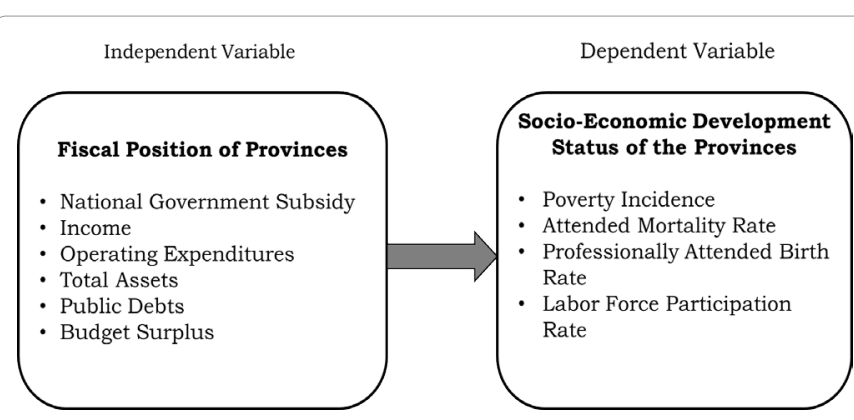

Figure 1: The conceptual paradigm showing the relationship of the variables of the study. 


\section{$\mathrm{H}_{\mathrm{a}} 1$ hypothesis}

There is a significant relationship between the independent variables fiscal position measured in terms of national government subsidy, income, operating expenditures, total assets, public debts, and budget surplus, and the dependent variables socio-economic development of the provinces measured in terms of poverty incidence, attended mortality rate, professionally attended birth rate, and labor force participation rate.

\section{$\mathrm{H}_{\mathrm{a}} 2$ hypothesis}

The independent variables fiscal position measured in terms of national government subsidy, income, operating expenditures, total assets, public debts, and budget surplus have significant influences on the socio-economic development of the provinces measured in terms of poverty incidence, attended mortality rate, professionally attended birth rate, and labor force participation rate; therefore, and the $\mathrm{r}^{2}$ values of the regression models and the beta coefficients of the independent variables are significantly greater than zero.

\section{Methodology}

\section{Research design}

This is a descriptive and predictive quantitative research, which used data in the form of numbers and statistics. Explicitly, the study is aimed at describing the fiscal position; describing the provinces' socioeconomic development; testing relationships between the variable; and structuring through multiple linear regression analysis the influence of fiscal position to the socio-economic development of provinces. Moreover, it is only applied between the variables that are tested and proven to have significant positive or negative correlation because according to Williams et, al. and Eckel $[9,10]$ the first assumption that has to be met in using regression analysis is that there needs to be a linear relationship between the independent and the dependent variable.

\section{Sources of data}

The study relied on secondary sources of data which are the official gazettes of the concern government agencies that are being published in their respective websites for public information and use. These government organizations include among others, the Commission on Audit (COA) [11] for the data on fiscal position of the provinces; the Philippine Statistical Authority (PSA) for the poverty and labor force statistics; and the Department of Health (DOH) [4,5] for the Philippine Health Statistics particularly attended mortality rate and professionally attended birth rate.

\section{Statistical treatment}

Pearson product-moment correlation was employed to determine the degree of association between the independent and the dependent variables. And multiple linear regression analysis was used to determine the degree of predictive influence of the various independent variables which are the fiscal position parameters to the dependent variables socio-economic development. Specifically, the said regression analysis was only done on variables tested and proven to have significant positive and negative correlations; these are between fiscal position and poverty incidence, between fiscal position and attended mortality rate, and between fiscal position and professionally attended birth rate.

\section{Results and Discussion}

\section{Relationship between fiscal position and socio-economic de- velopment of the provinces}

Presented in Table 1 are the results of the test of relationship between fiscal position and socio-economic development of the provinces using the Pearson Product-Moment Correlation otherwise known as Pearson r. As can be gleaned from the Table 1, all of the parameters of fiscal position which are national government subsidy, income, operational expenditure, total assets, public debts, and budget surplus are found to be with strong negative correlation with poverty incidence as indicated by the $\mathrm{r}$ values $-0.424,-0.452,-0.464,-0.430,-0.435$, and -0.454 respectively; and by the p value of 0.000 for all couple of variables. These figures show that as fiscal position raises, poverty incidence declines. Thus, we can say that the problem of poverty can be better addressed by a government that is financially capable.

On the other hand, very strong positive correlations are established between fiscal position particularly national government subsidy, income, operating expenditures, assets, and budget surplus as indicated by the $\mathrm{r}$ values $0.719,0.714,0.720,0.713$, and 0.731 respectively; and by the $p$ value of 0.000 for such pair of variables. On the other hand, strong correlation is found between public debts and attended mortality rate as shown by the $r$ value of 0.672 with the corresponding $p$ value of 0.000 . These numbers indicate that as fiscal position increases, attended mortality rate upsurges. These figures imply that, sick populace is better attended to when their government is financially ample.

Further, moderate positive correlation is found between fiscal position and professionally attended birth rate as revealed by the $r$ values $0.304,0.315,0.322,0.308,0.308$, and 0.324 accordingly; and by the $\mathrm{p}$ values $0.005,0.004,0.003,0.005,0.005$, and 0.003 correspondingly. These figures show that as fiscal position grows, professionally attended birth rate moderately increases. Thus, we can say that while a financially sufficient government is significant to serving the obstetrical concerns of the citizens who are expectant parents, the latter can make it even

\begin{tabular}{|c|c|c|c|c|c|c|c|c|}
\hline \multirow{2}{*}{$\begin{array}{l}\text { Fiscal } \\
\text { position }\end{array}$} & \multicolumn{2}{|c|}{$\begin{array}{l}\text { Poverty } \\
\text { incidence }\end{array}$} & \multicolumn{2}{|c|}{$\begin{array}{l}\text { Attended } \\
\text { mortality } \\
\text { rate }\end{array}$} & \multicolumn{2}{|c|}{$\begin{array}{c}\text { Professionally } \\
\text { attended birth } \\
\text { rate }\end{array}$} & \multicolumn{2}{|c|}{$\begin{array}{c}\text { Labor force } \\
\text { participation } \\
\text { rate }\end{array}$} \\
\hline & $\begin{array}{c}r \\
\text { value }\end{array}$ & $p$ value & $\begin{array}{c}r \\
\text { value }\end{array}$ & $\begin{array}{c}\mathbf{p} \\
\text { value }\end{array}$ & $\begin{array}{c}r \\
\text { value }\end{array}$ & $p$ value & $\begin{array}{c}r \\
\text { value }\end{array}$ & $\begin{array}{c}p \\
\text { value }\end{array}$ \\
\hline $\begin{array}{l}\text { National } \\
\text { government } \\
\text { subsidy }\end{array}$ & -0.424 & 0.000 & 0.719 & 0.000 & 0.304 & 0.005 & -0.122 & 0.270 \\
\hline Income & -0.452 & 0.000 & 0.714 & 0.000 & 0.315 & 0.004 & -0.169 & 0.128 \\
\hline $\begin{array}{l}\text { Operational } \\
\text { expenditure }\end{array}$ & -0.464 & 0.000 & 0.720 & 0.000 & 0.322 & 0.003 & -0.182 & 0.100 \\
\hline Total assets & -0.430 & 0.000 & 0.713 & 0.000 & 0.308 & 0.005 & -0.130 & 0.241 \\
\hline Public debts & -0.435 & 0.000 & 0.672 & 0.000 & 0.308 & 0.005 & -0.152 & 0.171 \\
\hline $\begin{array}{l}\text { Budget } \\
\text { surplus }\end{array}$ & -0.454 & 0.000 & 0.731 & 0.000 & 0.324 & 0.003 & -0.096 & 0.386 \\
\hline \multicolumn{9}{|c|}{ Legends } \\
\hline \multicolumn{3}{|c|}{ Pearson r Value } & \multicolumn{6}{|c|}{ Description } \\
\hline \multicolumn{3}{|c|}{0.70 or higher } & \multicolumn{6}{|c|}{ Indicates a very strong positive relationship. } \\
\hline \multicolumn{3}{|c|}{0.40 to 0.69} & \multicolumn{6}{|c|}{ Indicates a strong positive relationship. } \\
\hline \multicolumn{3}{|c|}{0.20 to 0.39} & \multicolumn{6}{|c|}{ Indicates a moderate positive relationship. } \\
\hline \multicolumn{3}{|c|}{-0.19 to 0.19} & \multicolumn{6}{|c|}{ Indicates no relationship. } \\
\hline \multicolumn{3}{|c|}{-0.20 to -0.39} & \multicolumn{6}{|c|}{ Indicates a moderate negative relationship. } \\
\hline \multicolumn{3}{|c|}{-0.40 to -0.69} & \multicolumn{6}{|c|}{ Indicates a strong negative relationship. } \\
\hline \multicolumn{3}{|c|}{-0.70 or lower } & \multicolumn{6}{|c|}{ Indicates a very strong negative relationship } \\
\hline
\end{tabular}

Table 1: Correlation between fiscal position and socio-economic development of the provinces. 
with modest government intervention. Most probably because, the nine-month gestation period is long enough for responsible parents to prepare. Unlike death or mortality of whatever manner which comes unexpected. Apparently, professionally attended birth rate is a product of many other significant factors.

Furthermore, no linear correlation is found between fiscal position and labor force participation rate as exhibited by the $r$ values -0.122 , $-0.169,-0.182,-0.130,-0.152$, and -0.096 respectively. These figures do not necessarily mean that a government's fiscal status is immaterial to labor force participation rate; rather these go to show that employment is a product of many other factors.

As a final point, it is therefore statistically appropriate to proceed with multiple linear regression analysis to determine the specific degree of influence of the various fiscal position parameters to the three dependent variables namely poverty incidence, attended mortality rate, and professionally attended birth rate. On the contrary, it is not apt to employ such analysis with labor force participation rate as dependent variable because according to Williams et al. and Eckel $[9,10]$ the first assumption that has to be met in using regression analysis is that there needs to be a linear relationship between the independent and the dependent variable.

\section{Multiple regression analyses}

Discussed below are the results of the multiple linear regression analysis between the six parameters of fiscal position and the three dependent variables these have been confirmed to be of significant relationship with poverty incidence, attended mortality rate, and professionally attended birth rate.

\section{Between fiscal position and poverty incidence}

Table 2 shows the multiple linear regression model summary and overall fit statistics. The adjusted $\mathrm{R}^{2}$ of the model that is 0.237 with the $\mathrm{R}^{2}$ of 0.293 mean that only $29.3 \%$ of the variations in the poverty incidence among the provinces can be explained by the variables national government subsidy, income, operating expenditures, total assets, public debts, and budget surplus. The Durbin-Watson statistics of 1.539 which indicates no first order autocorrelation or the relationship between a given variable and itself, confirms the validity of the predictive value of the linear regression model.

Presented in Table 3 is the multiple linear regression's F-test which has the null hypotheses that there is no linear relationship between fiscal position and poverty incidence; and that the $\mathrm{R}^{2}$ value is equal

\begin{tabular}{|c|c|c|c|c|}
\hline $\mathbf{R}$ & R square & Adjusted R square & e $\begin{array}{c}\text { Standard error of } \\
\text { the estimate }\end{array}$ & $\begin{array}{l}\text { Durbin- } \\
\text { Watson }\end{array}$ \\
\hline 0.541 & 0.293 & 0.237 & 11.52462 & 1.539 \\
\hline \multicolumn{3}{|c|}{ Durbin-Watson } & \multicolumn{2}{|c|}{ Description } \\
\hline \multicolumn{3}{|c|}{ Above 2.5 to 4} & \multicolumn{2}{|c|}{ Indicates negative auto correlation } \\
\hline \multicolumn{3}{|c|}{1.5 to 2.5} & \multicolumn{2}{|c|}{ Indicates no autocorrelation. } \\
\hline \multicolumn{3}{|c|}{ Less than 1.5} & \multicolumn{2}{|c|}{ Indicates positive autocorrelation } \\
\hline
\end{tabular}

Table 2: Model summary of the regression analysis between fiscal position and poverty incidence.

\begin{tabular}{|c|c|c|c|c|c|}
\hline Model & $\begin{array}{l}\text { Sum of } \\
\text { squares }\end{array}$ & df & $\begin{array}{l}\text { Mean } \\
\text { square }\end{array}$ & $\mathbf{F}$ & $\begin{array}{c}\text { Sig. } \\
\text { (p-value) }\end{array}$ \\
\hline Regression & 4178.434 & 6 & 696.406 & \multirow{3}{*}{5.243} & \multirow{3}{*}{0.000} \\
\hline Residual & 10094.083 & 76 & 132.817 & & \\
\hline Total & 14272.517 & 82 & - & & \\
\hline
\end{tabular}

Table 3: ANOVA table of the regression analysis between fiscal position and poverty incidence.

\begin{tabular}{|c|c|c|c|c|c|}
\hline \multirow{2}{*}{$\begin{array}{l}\text { Independent } \\
\text { variables }\end{array}$} & \multicolumn{2}{|c|}{$\begin{array}{l}\text { Unstandardized } \\
\text { coefficients }\end{array}$} & \multirow{2}{*}{$\begin{array}{c}\begin{array}{c}\text { Standardized } \\
\text { coefficient }\end{array} \\
\text { Beta }\end{array}$} & \multirow{2}{*}{$\mathbf{t}$} & \multirow{2}{*}{$\begin{array}{c}\text { Sig. } \\
\text { (p-value) }\end{array}$} \\
\hline & Beta & $\begin{array}{l}\text { Standard } \\
\text { error }\end{array}$ & & & \\
\hline Constant & 33.547 & 2.394 & - & 14.015 & 0.000 \\
\hline NG subsidy & -0.010 & 0.013 & -0.378 & -0.769 & 0.444 \\
\hline Income & -0.003 & 0.009 & -0.603 & -0.299 & 0.766 \\
\hline $\begin{array}{l}\text { Operational } \\
\text { expenditure }\end{array}$ & -0.005 & 0.007 & -1.028 & -0.731 & 0.467 \\
\hline Total assets & -0.005 & 0.012 & -0.898 & -0.391 & 0.697 \\
\hline Public debts & -.001 & .012 & -.268 & .120 & .905 \\
\hline Budget surplus & -.018 & .007 & -1.790 & -2.567 & .012 \\
\hline \multicolumn{6}{|c|}{ Dependent Variable: Poverty incidence } \\
\hline
\end{tabular}

Table 4: Coefficients table of the regression analysis between fiscal position and poverty incidence.

\begin{tabular}{|c|c|c|c|c|}
\hline $\mathbf{R}$ & R square & Adjusted R square & $\begin{array}{c}\text { Standard error of } \\
\text { the estimate }\end{array}$ & $\begin{array}{c}\text { Durbin- } \\
\text { Watson }\end{array}$ \\
\hline 0.755 & 0.570 & 0.536 & 7.96490 & 1.591 \\
\hline \multicolumn{4}{|c|}{ Durbin-Watson Description } \\
\hline \\
\multicolumn{3}{|r|}{ Above 2.5 to 4} & Indicates negative auto correlation \\
\hline & 1.5 to 2.5 & Indicates no autocorrelation. \\
\hline
\end{tabular}

Table 5: Model summary table of the regression analysis between fiscal position and attended mortality rate.

to zero. As shown in the Table 3, the F value of 5.243 that is highly significant as defined by the probability value of 0.000 , indicates that there is a linear relationship between the variables in the model; and that the predictive value of the model or the $\mathrm{R}^{2}$ value is significantly greater than zero. Thus, the null hypotheses are rejected.

Shown in Table 4 is the multiple linear regression estimates including the intercept or the constant value of the dependent variable when the independent variables are equal to zero, and the significance level or the probability values. As can be gleaned from the Table 4, poverty incidence will be constant at 33.547 percent when the value of the fiscal position parameters are equal to zero, holding all other factors constant. Only the budget surplus has a significant negative effect to poverty incidence with a coefficient which is significantly greater than zero, that is -0.018 or 1.8 percent, and a probability value of 0.012 . It explicitly means that for every million increases in the budget surplus, there will be a corresponding 1.8 percent drop in poverty incidence, considering all other factors constant.

On the other hand, the negative influences of other fiscal position parameters to poverty incidence are not significantly greater than zero and these are indicated by the coefficients - .010 for national government subsidy; -0.003 for income; -0.005 for operating expenditures; another -0.005 for total assets; and -0.001 for public debts. More specifically, these figures mean that for every million increase in national government subsidy, there will be a parallel reduction of 1 percent in poverty incidence; a million increase in income will have a 0.3 percent equivalent decline in poverty incidence; a million increment in operating expenditures has a matching decrease in poverty incidence of 0.5 percent; every million addition to total assets has a corresponding 0.5 percent decline in poverty incidence; and for every million increase in public indebtedness there will be a parallel fall in poverty incidence of 0.1 percent.

\section{Between fiscal position and attended mortality rate}

Table 5 is the multiple linear regression model summary and overall fit statistics. The adjusted $\mathrm{R}^{2}$ of the regression model that is 0.536 with 
the $\mathrm{R}^{2}$ value of 0.570 , indicate that 57 percent of the variations in the attended mortality rate among the provinces can be explained by the variables national government subsidy, income, operating expenditures, total assets, public debts, and budget surplus. The Durbin-Watson statistics of 1.591 which indicates no first order autocorrelation or the relationship between a given variable and itself, supports the validity of the predictive value of this linear regression model.

Table 6 shows the multiple linear regression's F-test which has the null hypotheses that there is no linear relationship between fiscal position and attended mortality rate; and that the $\mathrm{R}^{2}$ value is equal to zero. The $\mathrm{F}$ value of 16.786 that is highly significant as indicated by the probability value of 0.000 , denotes that there is a linear relationship between the variables in the model and that the predictive value of the model or the $\mathrm{R}^{2}$ is significantly greater than zero. Hence, the null hypotheses are rejected.

Shown in Table 7 is the multiple linear regression estimates including the intercept or the constant value of the dependent variable when the independent variables are equal to zero and the corresponding probability values or significance level. As presented in the Table 7, attended mortality rate is constant at 20.498 percent when the values of the fiscal position parameters are equal to zero.

Further, none of the coefficients in the parameter estimates is significantly greater than zero. Therefore, none of the fiscal position parameters national government subsidy, income, operational expenditures, assets, public debts, and budget surplus significantly influence attended mortality rate as indicated by their coefficients $0.007,0.007,0.009,0.007,0.005$, and 0.006 respectively; and by their probability values of $0.455,0.252,0.069,0.381,0.302$, and 0.340 correspondingly. In other words, their impact is not significantly greater than 0 . More specifically these figures mean that holding all other environmental forces constant, every million increment in national government subsidy, means a parallel increase of 0.7 percent in the attended mortality rate; a million rise in income will also have a 0.7 percent corresponding increase in the attended mortality rate; for every million growth in operational expenditure, there will be a matching 0.9 percent increment in the attended mortality rate; a million rise in total assets has a corresponding increase in the attended mortality rate of 0.7 percent; every million addition in public debts means a 0.5 percent

\begin{tabular}{|c|c|c|c|c|c|}
\hline Model & $\begin{array}{c}\text { Sum of } \\
\text { squares }\end{array}$ & df & $\begin{array}{c}\text { Mean } \\
\text { square }\end{array}$ & F & $\begin{array}{c}\text { Sig. } \\
\text { (p-value) }\end{array}$ \\
\hline Regression & 6389.254 & 6 & 1064.876 & & \\
\cline { 1 - 4 } Residual & 4821.408 & 76 & 63.440 & \multirow{2}{*}{16.786} & 0.000 \\
\hline Total & 11210.661 & 82 & - & & \\
\hline
\end{tabular}

Table 6: ANOVA table of the regression analysis between fiscal position and attended mortality rate.

\begin{tabular}{|c|c|c|c|c|c|}
\hline \multirow{2}{*}{$\begin{array}{c}\text { Independent } \\
\text { variables }\end{array}$} & \multicolumn{2}{|c|}{$\begin{array}{c}\text { Unstandardized } \\
\text { coefficients }\end{array}$} & $\begin{array}{c}\text { Standardized } \\
\text { coefficient }\end{array}$ & \multirow{2}{*}{$\mathbf{t}$} & $\begin{array}{c}\text { Sig. } \\
\text { (p-value) }\end{array}$ \\
\cline { 2 - 6 } & Beta & Standard error & Beta & & \\
\hline Constant & 20.498 & 1.654 & - & 12.391 & 0.000 \\
\hline NG subsidy & 0.007 & 0.009 & 3.330 & 0.750 & 0.455 \\
\hline Income & 0.007 & 0.006 & 1.816 & 1.154 & 0.252 \\
\hline $\begin{array}{c}\text { Operational } \\
\text { expenditure }\end{array}$ & 0.009 & 0.005 & 2.027 & 1.848 & 0.069 \\
\hline Total assets & 0.007 & 0.008 & 5.100 & 0.882 & 0.381 \\
\hline Public debts & 0.005 & 0.009 & 1.807 & 1.040 & 0.302 \\
\hline Budget surplus & 0.006 & 0.005 & .522 & 0.961 & 0.340 \\
\hline Dependent variable: Attended mortality rate & & & \\
\hline
\end{tabular}

Table 7: Coefficients table of the regression analysis between fiscal position and attended mortality rate.

\begin{tabular}{|c|c|c|c|c|}
\hline $\mathbf{R}$ & R square & Adjusted $R$ square & e $\begin{array}{c}\text { Standard error of } \\
\text { the estimate }\end{array}$ & $\begin{array}{l}\text { Durbin- } \\
\text { Watson }\end{array}$ \\
\hline 0.432 & 0.187 & 0.123 & 17.81428 & 1.713 \\
\hline \multicolumn{5}{|c|}{ Legend } \\
\hline \multicolumn{3}{|c|}{ Durbin-Watson } & \multicolumn{2}{|c|}{ Description } \\
\hline \multicolumn{3}{|c|}{ Above 2.5 to 4} & \multicolumn{2}{|c|}{ Indicates negative auto correlation } \\
\hline \multicolumn{3}{|c|}{1.5 to 2.5} & \multicolumn{2}{|c|}{ Indicates no autocorrelation. } \\
\hline \multicolumn{3}{|c|}{ Less than 1.5} & \multicolumn{2}{|c|}{ Indicates positive autocorrelation } \\
\hline
\end{tabular}

Table 8: Model summary table of the regression analysis between fiscal position and professionally attended birth rate.

\begin{tabular}{|c|c|c|c|c|c|}
\hline Model & $\begin{array}{c}\text { Sum of } \\
\text { squares }\end{array}$ & df & $\begin{array}{c}\text { Mean } \\
\text { square }\end{array}$ & F & $\begin{array}{c}\text { Sig. } \\
\text { (p-value) }\end{array}$ \\
\hline Regression & 5546.728 & 6 & 924.455 & & \\
\hline Residual & 24118.492 & 76 & 317.349 & 2.913 & 0.013 \\
\hline Total & 29665.220 & 82 & & & \\
\hline
\end{tabular}

Table 9: ANOVA table of the regression analysis between fiscal position and professionally attended birth rate.

\begin{tabular}{|c|c|c|c|c|c|}
\hline \multirow{2}{*}{$\begin{array}{l}\text { Independent } \\
\text { variables }\end{array}$} & \multicolumn{2}{|c|}{$\begin{array}{l}\text { Unstandardized } \\
\text { coefficients }\end{array}$} & \multirow{2}{*}{\begin{tabular}{|c|}
$\begin{array}{c}\text { Standardized } \\
\text { coefficient }\end{array}$ \\
Beta \\
\end{tabular}} & \multirow{2}{*}{$\mathbf{t}$} & \multirow{2}{*}{$\begin{array}{c}\text { Sig. } \\
(p-\text {-value })\end{array}$} \\
\hline & Beta & Standard error & & & \\
\hline Constant & 62.038 & 3.632 & - & 17.080 & 0.000 \\
\hline NG subsidy & 0.007 & 0.025 & 0.341 & 1.702 & 0.093 \\
\hline Income & 0.006 & 0.013 & 0.212 & 0.428 & 0.670 \\
\hline $\begin{array}{l}\text { Operational } \\
\text { expenditure }\end{array}$ & 0.001 & 0.011 & 0.071 & 0.116 & 0.908 \\
\hline Total assets & 0.039 & 0.020 & 4.804 & 1.959 & 0.053 \\
\hline Public debts & 0.035 & 0.018 & 2.292 & 1.940 & 0.054 \\
\hline $\begin{array}{l}\text { Budget } \\
\text { surplus }\end{array}$ & 0.008 & 0.013 & 0.404 & 1.362 & 0.177 \\
\hline
\end{tabular}

Dependent variable: Professionally attended birth rate

Table 10: Coefficients table of the regression analysis between fiscal position and professionally attended birth rate.

parallel raise in the attended mortality rate; and lastly, for every million rise in budget surplus, there will be a 0.6 percent corresponding surge in the attended mortality rate.

\section{Between fiscal position and professionally attended birth rate}

The multiple linear regression model summary and overall fit statistics are shown in Table 8 . The adjusted $\mathrm{R}^{2}$ of the regression model that is 0.123 with the $\mathrm{R}^{2}$ value of 0.187 , imply that only 18.7 percent of the variations in the professionally attended birth rate among the provinces can be explained by the fiscal position parameters national government subsidy, income, operating expenditures, total assets, public debts, and budget surplus. Meanwhile, the Durbin-Watson statistics of 1.713 which means no first order autocorrelation or the relationship between a given variable and itself, authenticates the predictive value of the linear regression model, however slight it is, at only 18.70 percent.

Table 9 shows the multiple linear regression's F-test which has the null hypotheses that there is no linear relationship between fiscal position and professionally attended birth rate; and that the $\mathrm{R}^{2}$ value is equal to zero. As shown, the $\mathrm{F}$ value of 2.913 is significant as indicated by the probability value of 0.013 . These values mean that a significant linear relationship between fiscal position parameters and professionally attended birth rate exits; and that the $\mathrm{R}^{2}$ value is significantly greater than zero. Thus, the abovementioned hypotheses, are rejected.

Presented in Table 10 is the multiple linear regression estimates including the intercept or the constant value of the dependent variable when the independent variables are equal to zero, and the corresponding probability values or significance levels. As the Table 10 
shows, professionally attended birth rate will be at 62.038 percent when the values of the fiscal position parameters are equal to zero.

Further, the Table shows that two of the fiscal position parameters have statistically significant influence to professionally attended birth rate as indicated by their coefficients and corresponding probability values. These are total assets, with a coefficient of 0.039 and a probability value of 0.053; and public debts, with a coefficient of 0.035 and a probability value of 0.054 . Moreover, these figures specifically entail that for every million growth in total assets, there will be a parallel 3.9 percent increase in the professionally attended birth rate; and every million increase in public debts will have a corresponding 3.5 percent rise in the professionally attended birth rate.

Moreover, the influences of other fiscal position parameters to professionally attended birth rate are not statistically significant. These parameters include, national government subsidy, income, operational expenditure, and budget surplus as indicated by their coefficients of $0.007,0.006,0.001$, and 0.008 ; and probability values of $0.093,0.670$, 0.908 , and 0.177 respectively. However not significantly greater than zero are the influence of these factors, the numbers specifically indicate that holding all other environmental forces constant, every million increase in subsidy has a corresponding 0.7 percent rise in professionally attended birth rate; every million growth in income will have a parallel increase of 0.06 percent in professionally attended birth rate; every million increase in operational expenditure has a matching 0.1 rise in professionally attended birth rate; and every million raise in budget surplus has an equivalent 0.8 percent increase in professionally attended birth rate.

\section{Conclusion and Recommendations}

\section{Conclusion}

From the test of relationships between the variables of the study, following conclusions are drawn.

1. There are strong negative correlations between all the fiscal position parameters and poverty incidence.

2. There are very strong positive correlations between fiscal position parameters namely national government subsidy, income, operational expenditure, total assets, and budget surplus and the dependent variable, attended mortality rate.

3. There is a strong positive correlation between public debts and attended mortality rate.

4. There are moderate positive correlations between all the fiscal position parameters and professionally attended birth rate.

5. There are no correlations between fiscal position and labor force participation rate.

Meanwhile, on the multiple linear regression analysis done between the fiscal position and poverty incidence, following conclusions are drawn.

1. At a 29.3 percent predictive capability of the regression model, and at 33.547 percent constant value of the dependent variable budget surplus is found to have a significant reduction power to poverty incidence, therefore the null hypothesis is rejected.

2. At a 57 percent predictive capability of the regression model and at 20.498 percent constant value of the dependent variable, none of the six fiscal position parameters is found to have a significant influence, on attended mortality rate, hence the null hypothesis is accepted.
3. At an 18.7 percent predictive capability of the regression model and at 62.038 percent constant value of the dependent variable, two of the six fiscal position parameters namely, total assets and public debts, are found to have significant increasing powers to professionally attended birth rate, therefore the null hypothesis is rejected.

\section{Recommendations}

1. As the national government subsidy distribution scheme, or to be more specific the IRA distribution scheme, seems to lack some equalizing features such that the Mindanao Regions are getting much less, it is imperative for policy makers to review all laws relative to national and local fiscal administration in order that Mindanao Regions can get more.

2. Policy makers may consider giving Local Government Units share from customs collection and not just from internal revenue; and consider amendments on tax assignments and revenue mandates of LGUs. Moreover, greater fiscal autonomy for LGUs through federalism may also be a good approach since it will possibly distribute wealth across the country evenly instead of bulk going to the imperial NCR.

3. Considering the present institutional arrangements or laws on fiscal administration, it is imperative for all national government agencies as well as for concern Non-Government Organizations to give extra focus on and implement more poverty alleviation programs that are tailored fit for Mindanao Regions' poverty problems and as well for other regions with relatively higher poverty incidence.

4. Since attended mortality and professionally attended birth rates are quite low in the Philippines, it is therefore imperative for decision makers both in the local and national levels to rebalance efforts in the health field to do far more to promote health and prevent diseases. This will require raising competencies, profiles, and incentives of health promotion and diseases prevention professionals; a stronger health promotion curriculum in schools; and an improved legal, operational, and management framework of health units at the national and local government levels with clearer roles and responsibilities, and more budgets.

5. As full utilization of the labor force continues to be a pressing concern given the 66.83 labor force participation rate, it is imperative for decision makers to place creating jobs at the center of social and economic policy making of the local and national governments.

6. Because LGUs are tasked to manage development of all aspects in their respective jurisdictions, and because fiscal position parameters are influential however at varying degrees to socio-economic development, and given the current fiscal administration set up, it is imperative for LGUs to improve their revenue generating capacity through intensifying tax collection measures; to allocate fiscal resources based on strategic priorities; and to efficiently and effectively utilize resources in the implementation of strategic priorities.

\section{References}

1. Philippine Statistical Authority (2014) National statistical coordination board (PSA-NSCB). Labor force statistics.

2. Balisacan AM (2015) Poverty reduction: What we know and don't know. Philippine Daily Inquirer: Opinion.

3. Eduardo ZR, Yoingco AQ, Casem AO (2006) Philippine public finance. Manila: GIC Enterprises and Co.

4. Department of Health (2012) National epidemiology center. The Philippine Health Statistics (2007, 2008, 2009, 2010, 2011 and 2012).

5. Philippine Statistical Authority (2006) National statistical coordination board (PSA-NSCB). Full year official poverty statistics. 
Citation: Aguilar AP (2017) The Influence of Fiscal Position to the Socio-Economic Development of the Provinces in the Philippines. Review Pub Administration Manag 5: 232. doi:10.4172/2315-7844.1000232

Page 8 of 8

6. Roy R, Weeks J (2010) Making fiscal policy work for the Poor. United Nations Development Program (UNDP).

7. Briones ML (1996) Philippine public fiscal administration. Mandaluyong City, Manila: Fiscal Administration Foundation Inc.

8. Jose LP (2008) Public administration: The Business of government. Manila: National bookstore, Mandaluyong City, Philippine.
9. Williams MN, Grajales CA, Kurkiewicz D (2013) Assumptions of multiple regression: Correcting two misconceptions. J Elect 18: 1-14.

10. Sandy E (2008) Linear regression approach, assumptions, and diagnostics.

11. Commission on Audit (COA) (2012) Annual financial report. Local governments (Provinces, cities, municipalities, and barangays). 